\title{
ФЕРМЕНТАТИВНО СИНТЕЗИРОВАННЫЙ ГИДРОКСИАПАТИТ КАК НОСИТЕЛЬ РАДИОНУКЛИДОВ ИТТРИЯ И РУТЕНИЯ
}

\author{
В.К. Долгова, А.В. Гопин, А.Л. Николаев, А.В. Северин, \\ М.А.Орлова
}

Химический факультет, МГУ им. М.В. Ломоносова, 119991, Россия, Москва, Ленинские горы, 1,с.3.

DOI: 10.19163/MedChemRussia2021-2021-277

E-mail:varya.dolgova@mail.ru

Данная работа посвящена созданию и характеризации свойств носителя на основе ферментативного гидроксиапатита для радионуклидов иттрия и рутения, а также апробация меченого рутением-97 органо-комплекса in vivo, как прототипа радиофармацевтического агента. Ферментативный метод является одним из наиболее перспективных для создания частиц носителя на основе гидроксиапатита для применения в методе радиоэмболизации. Он основан на ферментативном гидролизе органического фосфата в среде, содержащей ионы кальция. Гидролизом глицерофосфата кальция в присутствии щелочной фосфатазы были синтезированы сферические частицы гидроксиапатита с развитым рельефом поверхности. Их средний диаметр составлял 3 мкм, удельная поверхность - 130 м²/г и объем пор - 0,4 см³/г.

На модельных сорбатах (ионы меди, конго красный) было показано, что сорбция протекает достаточно быстро, при этом достигаются высокие значения удельной сорбции. Проводили сорбцию целевых радионуклидов ${ }^{90} \mathrm{Y}$ и $\left.{ }^{103} \mathrm{Ru}\right)$ на ферментативном гидроксиапатите. Для иттрия характерна быстрая кинетика, выход на плато достигается за 15 минут. Максимальная сорбция составляет 500 мг/г. При этом десорбция практически не наблюдается. Для рутения выход на плато достигается за 60 минут, максимальная сорбция значительно меньше, чем для иттрия, и составляет 18 мг/г, при этом в некоторых случаях наблюдается значимая десорбция. Из-за этого возможны потери нуклида в организме. В связи с этим проводили эксперименты на модельных животных. Было определено распределение и накопление препаратов ${ }^{97} \mathrm{RuCl}_{4}$ и ${ }^{97} \mathrm{Ru}$-комплекс с (2S,2’S)-2,2'-[пиридин-2,6-диилбис(карбонилимино)]бис(4метилмульфанил бутановой кислотой) в органах мышей CD1 при внутрибрюшинном введении. Наибольшее накопление наблюдается в почках, печени и селезенке. Также наблюдается накопление комплекса в легких, что может применяться в терапии заболеваний легких.

Таким образом, ферментативно синтезированный гидроксиапатит может быть использован в качестве носителей радионуклидов иттрия и рутения для метода радиоэмболизации. 